\title{
A SENTENÇA ARBITRAL FRENTE ÀS NOVAS ALTERAÇÕES DO CÓDIGO DE PROCESSO CIVIL BRASILEIRO E SUA IMPUGNAÇÃO NOS CASOS DE INEXISTÊNCIA
}

\section{ARBITRAL AWARD IN FACE OF THE NEW ALTERATIONS TO THE BRAZILIAN CODE OF CIVIL PROCEDURE AND ITS IMPUGNATION IN CASES OF ABSENCE}

\author{
Marcia dos Santos Eiras" \\ Rozane da Rosa Cachapuz"
}

\begin{abstract}
Resumo: O presente trabalho tem por escopo abordar a forma pela qual o conceito de sentença adotado atualmente pelo Código de Processo Civil altera a estrutura da sistemática processual em que foi moldada a Lei 9.307/96, abrindo possibilidade de utilização de novas modalidades de sentença, entre elas a parcial, sua impugnação, aí inclusa a utilização de ação de natureza declaratória para este fim.
\end{abstract}

Palavras-chave: Sentença arbitral. Sentença arbitral parcial. Processo. Impugnação. Sentença declaratória.

\begin{abstract}
The present paper addresses the way in which the concept of sentence currently adopted by the Code of Civil Procedure alters the structure of the procedural system in which Law 9.307/96 was formed, enabling the possibility of utilizing new ways of ruling, amongst them the partial award and its impugnation, considering the prospect of utilizing an action of declaratory nature towards this end in cases where it happens to have no legal validity.
\end{abstract}

Key-words: Arbitral award. Partial arbitral award. Process. Impugnation. Declaratory sentence.

\section{INTRODUÇÃO}

A idéia deste trabalho pode ser debitada grande parte à repercussão da crise do acesso à Justiça, a lentidão na tramitação dos processos, agravada pelo excesso de instâncias recursais; provocando insuportável demora na prestação da tutela jurisdicional, além da deficiência dos serviços de assistência judiciária... Observado isto, nota-se, pela pesquisa acadêmica, que por essas e outras razões

\footnotetext{
Mestranda em Direito Negocial (Processo civil), pela Universidade Estadual de Londrina (UEL/PR). Email: marciaseiras@hotmail.com

"Mestre em Direito Negocial (Civil e Processo Civil), pela Universidade Estadual de Londrina (UEL/PR) e Doutora em Relações Sociais, com ênfase em direito de família, pela Pontifícia Universidade Católica de São Paulo (PUC/SP). Email: rozane_ cachapuz@hotmail.com
} 
o processo civil passa por profundas modificações, sendo que tais mudanças evoluem para o incentivo à resolução dos conflitos seja através da mediação, negociação, conciliação ou arbitragem - por iniciativa das partes.

Inicialmente, sem necessidade de enfrentar as tormentosas discussões que se travam no terreno da arbitragem, tem-se que a Lei 9.307/96 [que regulamenta todo o procedimento arbitral] estabelece com base no princípio da autonomia $\mathrm{da}$ vontade permissão às partes para solucionarem, fora da órbita estatal, em sede privada, questões atinentes a direitos disponíveis seus.

Entretanto, considerando as recentes alterações promovidas pela Lei 11.232/05 no Código de Processo Civil, no que diz respeito ao conceito de sentença e seu cumprimento, convém ressaltar que esta alterou sensivelmente a estrutura da sistemática processual em que a Lei de Arbitragem foi moldada, gerando abertura para novas discussões referentes a seus institutos à luz do ordenamento jurídico vigente.

Anote-se que, em razão do conceito de sentença atualmente adotado pelo Código de Processo Civil, é possível aventar a possibilidade de sentenças parciais em sede de arbitragem, o que atende aos imperativos no âmbito de resolução de conflitos comerciais complexos, bem como a possibilidade de execução de sentença declaratória. Execução esta considerada, pela maioria da doutrina, inexeqüível nos moldes anteriores.

$\mathrm{Na}$ conformidade das inovações trazidas pela Lei $11.232 / 05$ no caso de execução de título executivo judicial ou cumprimento da sentença pretende-se demonstrar em que medida tais alterações refletem na análise e aplicação da Lei de Arbitragem na atualidade.

Argumenta-se, ainda, a possibilidade de impugnação da sentença, através de ação de natureza declaratória, nos casos em que a decisão apresente vício grave que impeça a produção de seus efeitos, ensejando, dessa forma a inexistência jurídica da sentença.

\section{SENTENÇA ARBITRAL}

A Lei 9.307/96 estabelece que a decisão do árbitro consiste em sentença e deve, portanto, adotar a forma escrita, conquanto que tem a mesma eficácia do provimento judicial transitado em julgado (arts 18, 23, 24 e 31) ${ }^{1}$.

A sentença, analisada sob seu aspecto formal, pode ser conceituada como o ato do julgador proferido conforme arts 267 e 269 do CPC, qual seja,

${ }^{1}$ A Lei 9.307/96 considera estrangeira a sentença arbitral proferida fora do território nacional, aos moldes da Lei Espanhola de Arbitragem e da Convenção de Nova Iork. 
independentemente de apreciar-lhe o mérito ou não, nos termos do art. $162 \S$ $1^{\circ}$ do CPC. Por essa perspectiva, apresenta-se sob duas formas:

a) quando apenas apresenta conteúdo meramente processual, em razão de invalidade de compromisso arbitral ou nos casos do art. 12, I e II da Lei de Arbitragem, por exemplo;

b) quando reconhece o direito de uma das partes, podendo ser condenatória, constitutiva ou declaratória.

Vale lembrar que a doutrina, antes das alterações promovidas pela Lei 11.232/2005 que modificou o conteúdo do art. 162 do CPC, cujo dispositivo prestava-se, entre outras coisas, à definição de sentença, apresentava conceito de cunho finalístico desse provimento. Considerada ato que encerrava o processo, a sentença dispunha cunho terminativo: quando apenas finalizava o processo, sem discutir o mérito, ou definitiva, quando decidia o mérito.

Sob esse prisma, o conceito de sentença, trazido por Bellinetti (1994, p.145), apresenta dois aspectos: formal e material. No aspecto formal há perspectiva de sentença como "ato que encerra o processo, independente de julgar-lhe o mérito, ao lado daquele que entende sentença como o ato que julga o mérito do processo (resolve um litígio autônomo), funcionando subsidiariamente o conceito atinente a ato emitido sob determinada forma”. No aspecto material "implica uma reflexão não somente jurídica, mas também, psicológica, política e semiológica”. Nesse sentido aduz o autor:

No aspecto material há a perspectiva de sentença como ato que estabelece (declarando - declaração pura ou constituição ou criando) a norma que irá regrar o caso concreto, ao lado de um conceito mais amplo, colocando-se a sentença como o ato que se manifesta sobre o estabelecimento dessa norma, estabelecendo-a ou negando-se a fazê-lo (BELLINETTI, 1994, p. 145).

Para Carmona (2006, p.278) "a sentença arbitral, da mesma forma que a sentença proferida pelos órgãos jurisdicionais estatais, é o ato através do qual o julgador põe fim ao processo”. Porém, a partir da alteração ocorrida no CPC, em razão da reforma imposta pela Lei 11.232/2005, Carmona (2008, p. 15) alude que "ao contrário do que ocorre com a sentença proferida pelo juiz estatal, o árbitro, ao sentenciar, esgota sua função jurisdicional”, sinalizando que "a Lei de Arbitragem apostou, portanto (com sucesso) na definição finalística de sentença arbitral”.

A diferenciação entre as duas modalidades de sentença, apresentada por Nery Junior, (2002, p. 79), enfoca questão diversa:

Apenas se distanciam quanto ao aspecto confiança, que preside o negócio jurídico de compromisso arbitral, estando ausentes na jurisdição estatal, cujo 
órgão não pode ser escolhido pelas partes e cuja sentença é imposta coativamente aos litigantes. Enquanto no compromisso arbitral as partes convencionam acatar a decisão do árbitro, na jurisdição estatal o réu é compelido a responder o processo, ainda que contra sua vontade, sendo as partes obrigadas a obedecer ao comando emergente da sentença.

Entretanto, distinção fundamental entre a sentença proferida pelo árbitro e a proferida pelo magistrado reside no fato da primeira carecer de executividade, isto porque à jurisdição privada não se estende o poder de coerção, sendo este monopólio do estado. O cumprimento ao julgado integra, pois, a função jurisdicional estatal2 ${ }^{2}$.

A grande inovação, trazida pela Lei de Arbitragem $^{3}$, refere-se quanto à desnecessidade de homologação da decisão arbitral pelo órgão jurisdicional estatal, conforme ocorria anteriormente à sua publicação ${ }^{4}$. A natureza de título executivo judicial dado à sentença arbitral, anteriormente pelo art. 584, VI, do CPC e, após sua revogação pelo art. 475-N, IV da Lei 11.232/2005, só vem a reafirmar o caráter jurisdicional da arbitragem ${ }^{5}$, caracterizando-a como manifestação dessa atividade jurisdicional e, conseqüentemente, revestindo-a da autoridade da coisa julgada, que tem como resultado a imutabilidade e oponibilidade de exceção de coisa julgada. Segundo Parizzato (1997, p. 100-1):

A eficácia da sentença arbitral como título executivo judicial, decorre da própria prolação, havendo condenação, não mais necessitando essa de qualquer homologação pelo próprio órgão do poder Judiciário, como anteriormente se exigia. Desapareceu com a Lei no 9.307/96, a figura da homologação pelo Poder judiciário, pelo que a sentença proferida pelo árbitro ou pelo tribunal arbitral, terá eficácia de uma sentença proferida por tal órgão, independentemente de qualquer interferência deste.

${ }^{2}$ Segundo lições de Zanzucchi (1964, p. 15), os poderes que compõem a jurisdição são: a) notio (conhecer), b) imperium ( de coerção), c) documentação.

${ }^{3}$ O sistema legal brasileiro, anterior ao advento da Lei 9.037/96, utilizava a denominação de laudo arbitral para designar a decisão que finalizava a arbitragem, tal como ocorre até hoje no sistema espanhol.

${ }^{4}$ No direito comparado, alguns ordenamentos exigem a homologação da decisão arbitral por um juízo, entre eles o italiano.

${ }^{5}$ Muitos processualistas afirmam não haver atividade jurisdicional na função do árbitro, entre eles Teori Zavasccki e Marinoni (2006, p. 148) que defendem que a jurisdição só pode ser exercida por pessoa investida na autoridade de juiz, após concurso público de provas e títulos. Contudo, tal conceito deve ser revisitado, adotando-se posicionamento mais ampliativo, considerando-se que o objetivo último da jurisdição é a pacificação social e que a arbitragem é instituída sob a permissão estatal. Nesta esteira, a arbitragem é meio jurisdicional de solução de conflitos, cuja decisão do árbitro produz efeitos iguais às decisões proferidas pelo Judiciário. 
O prazo para a prolação de sentença arbitral, nos moldes da legislação pátria vigente, é de seis meses, a contar da instauração do processo arbitral, se outro não for o prazo estipulado pelas partes. Ao se estipular tal prazo, pretendia-se a celeridade processual, vantagem esta apresentada pela arbitragem frente ao processo estatal.

Constata-se através da análise dos dispositivos que disciplinam a decisão arbitral na Lei 9.307/96 que o referido diploma legal trabalhou com a idéia de unicidade da sentença arbitral. Entretanto, com o advento da Lei 11.232/2005, alteradora do Código de Processo Civil brasileiro, que visou à adaptação do conceito de sentença ao procedimento adotado para o cumprimento das sentenças, foi possibilitado, no dizer de Carmona (2008, p. 11-8) "o fatiamento do julgamento da lide”, quer seja na jurisdição estatal quanto na arbitral, posto que "alterou-se, portanto, o padrão do devido processo legal em que se espelhava a Lei de Arbitragem”. No mesmo sentido, Vargas (2007, p. 154):

Todavia, pelo novo conceito de sentença, trazido pela Lei 11.232/2005, este ato processual não é mais definido pelo seu efeito, mas pelo seu conteúdo, ou seja, não é o ato pelo qual o juiz, necessariamente, põe termo ao processo, mas sim o ato do juiz que implica algumas situações previstas nos arts. 267 e 269 do CPC, o que significa dizer que num processo, agora, poderão existir várias sentenças.

Contudo, no âmbito arbitral, para a utilização de técnica de julgamentos parciais, destaca Carmona (2008, p. 18) a necessidade de expressa referência em convenção arbitral, que enfatiza:

Doravante, o emprego da técnica do julgamento gradual e parcelado da lide servirá tanto para economizar tempo e dinheiro das partes, como também para evitar situações em que árbitros, por absoluta impossibilidade material, não conseguiriam proferir sentenças líquidas (como acontecia com as hipóteses lembradas das decisões sobre rescisão de contratos de franquia e respectivas indenizações).

No direito comparado, na Itália, desde os anos 50, após julgado da Corte de Cassação, foi reconhecido que não havia óbice para a admissão de sentenças arbitrais parciais. Igualmente na Espanha, que historicamente teve que superar barreiras culturais que antagonizavam com a adoção da arbitragem, em 2003, com a edição de nova Ley de Arbitraje restou disciplinada a sentença arbitral parcial. Conta ainda previsão expressa dessa modalidade de decisão as leis de arbitragem suíça e britânica.

Estendendo a questão de sentenças arbitrais parciais a outros sistemas, regras expressas de referências a laudos parciais estão presentes no art. $2^{\circ}$ do Regulamento de Arbitragem da Corte Internacional de Arbitragem da Câmara de Comércio Internacional, e no Regulamento da American Arbitration 
Association. A partir de 2005, tal referência também passou a ser expressa, excepcionalmente, no Regulamento do Centro de Arbitragem da Amcham (Câmara Americana de Comércio) de São Paulo, porém, com ressalvas de ratificação das decisões parciais em decisão final.

A adoção em sede arbitral de decisão parcial por parte do julgador, além de favorecer os interesses das partes, "facilitará (ou condicionará) o normal desenvolvimento de obrigações contratuais múltiplas" (CARMONA, 2008, p. 16). É também conveniente, em virtude de os "árbitros decidirem questão que demande liquidação em duas etapas distintas, uma objetivando o an debeatur, outra focando o quantum debeatur".

Todavia, surgirão problemas que deverão ser resolvidos no sentido de redimensionar o sistema de impugnação das decisões arbitrais parciais, adequar as previsões relativas às execuções de tais provimentos (e a disciplina de sua respectiva imutabilidade), bem como acomodar os prazos previstos na arbitragem (em especial, o prazo para proferir sentença) (CARMONA, 2008, p. 19).

Quanto à impugnação da sentença parcial, em especial nos termos do art 32 da Lei 9.307/96, será necessário que a demanda de nulidade seja manejada para atacá-la na proporção em que seja proferida a decisão, sob pena de não o fazendo, ou só impugnando a sentença final, a sentença parcial sobreviverá, mesmo que se obtenha sucesso no combate.

Ao final, reconhecida a obrigação líquida em sentença arbitral, nova questão surge mediante o não cumprimento espontâneo pela parte contra quem foi proferida a decisão, posto que será necessária a execução da sentença arbitral. Cumpre observar que no âmbito dos contratos internacionais, em que a arbitragem é largamente utilizada, é comum o cumprimento espontâneo da sentença arbitral. É evidente que isso ocorre em razão de que mediante o descumprimento, ou a necessidade de se recorrer ao judiciário para a efetivação da decisão, tal atitude resulta em descrédito, o que se mostra conseqüência nociva à atividade empresarial.

Entretanto, se necessário for socorrer-se do judiciário para o cumprimento do decisum, de acordo com a atual sistemática adotada pelo CPC, incidirá a hipótese do art 475-J, referente ao cumprimento de sentença, aplicando-se ao devedor condenado em sentença arbitral ao pagamento de quantia certa que não o faz no prazo de 15 dias, a partir da intimação da decisão (art 29 Lei 9.307/96), o acréscimo de multa no percentual de dez por cento ao quantum devido. Nessa esteira de pensamento, Scavone Junior (2008, p. 185) esclarece: 
Ultrapassado in albis o prazo de quinze dias, o credor deverá instruir o pedido de execução da obrigação de pagar quantia certa constante do título executivo judicial (art. 475-N, IV, do CPC) com cópia do processo arbitral bem como com planilha de cálculo (art. 614, II, do CPC), incluindo multa de 10\% (dez por cento) e requerendo, além da citação, a expedição de mandado de penhora e avaliação.

Tem-se que em se tratando de sentença arbitral mandamental ou executiva lato sensu, que implique em entrega de bem ou obrigação de fazer ou não fazer, o procedimento a ser adotado para o cumprimento do disposto na decisão é o determinado pelos arts 461 e 461-A do CPC, conforme determinam os arts 475-I e 644 do CPC. Nesse diapasão, Medina (2008, p. 292) assevera que:

A circunstância de o dever de entregar coisa constar de título executivo não impede que o demandante opte pelo rito do art. 461-A do CPC, que, tendo em vista a maior quantidade de medidas executivas que podem ser manejadas pelo juiz, pode propiciar ao autor uma tutela jurisdicional tendente a obter, mais prontamente, o bem devido, tendo em vista que à ação a que se refere o art. 461A aplicam-se as medidas executivas referidas nos parágrafos do art. 461 do CPC, a que se referiu acima.

Medina em suas considerações, após advento da Lei 11.232/2005 que acrescentou capítulo que trata do cumprimento de sentença no CPC, considera que com a redação dada ao artigo $475-\mathrm{N}, \mathrm{I}^{6}$, da letra da nova norma jurídica extrai-se que não só as sentenças condenatórias, mas também "as sentenças declaratórias podem constituir título executivo": Basta, para tanto, que a sentença reconheça a existência de obrigação, atribuindo ao efeito executivo da sentença declaratória secundariedade (MEDINA, 2006, p. 76).

De ver que em data anterior à reforma do CPC, Zavascki (2003, p. 56) já atestava que "não procede a afirmação de que a sentença meramente declaratória jamais é título executivo; ela terá força executiva quando contiver certificação de todos os elementos de uma norma jurídica concreta, relativa à obrigação”. Esse também foi o posicionamento adotado por ele ao relatar julgado no STJ em 2002, antes, portanto, da alteração legislativa (BRASIL, STJ, $1^{\circ}$ T., REsp 588.202/PR, j. 10.02.2004, DJ 25.02.2004, p. 123).

Para que a sentença declaratória seja considerada título executivo é imprescindível que contenha todos os elementos da relação jurídica obrigacional.

\footnotetext{
${ }^{6}$ Existem questionamentos quanto à inconstitucionalidade formal do dispositivo citado em razão do teor não constante do projeto original proposto na Câmara dos Deputados, surgido, apenas como emenda de redação no Senado Federal, não tendo ocorrido seu retorno à casa iniciadora conforme determinado pelo art 65 , parágrafo único, da Constituição Federal.
} 
Segundo Santos (2008, p. 185), pela redação dada ao art 475 - N, que apresenta o rol dos títulos executivos judiciais, a sentença declaratória "não tem o mesmo significado de sentença condenatória” contido anteriormente no art 584 do CPC, encontrando-se "alterada toda a estrutura da sistemática processual até então seguida, rompendo-a e superando-a”.

A alteração trazida pela inclusão do art. 475 - N do CPC leva à reflexão quanto à interpretação sistemática do ordenamento jurídico, aí inserida a Lei 9.307/96, favorecendo novas interpretações quanto à natureza da sentença arbitral. De qualquer sorte resta a imposição da equivalência da sentença arbitral com a sentença judicial, possuindo, as duas, a mesma eficácia para fins de execução. Nesse ponto, Carmona doutrina que a equiparação entre a sentença estatal e a arbitral faz com que a segunda produza os mesmos efeitos da primeira. Por conseqüência, além da extinção da relação jurídica processual e da decisão da causa (declaração, condenação ou constituição), a decisão de mérito faz coisa julgada às partes entre as quais é dada (e não beneficiará ou prejudicará terceiros) (CARMONA, 2004, p. 314).

\section{DA IMPUGNAÇÃO DA SENTENÇA ARBITRAL}

Após prolatar a sentença, deve o árbitro intimar as partes da decisão, resultando na extinção da jurisdição dos árbitros, não mais sendo possível a revisão da decisão. Apenas por requerimento das partes tal revisão será possível, mediante apresentação de embargos de declaração dentro do prazo de cinco (5) dias posteriores à comunicação às partes, cujo aditamento da decisão pelo árbitro se dará no prazo de dez (10) dias subseqüentes. A possibilidade de oposição de embargos surgirá mediante a ocorrência de hipóteses legais de admissibilidade do requerimento de esclarecimentos, quais sejam: erro material; dúvida fundada; omissão; contradição; obscuridade.

Uma vez extinta a jurisdição dos árbitros ocorre a produção dos efeitos $\mathrm{da}$ sentença em relação às partes, produzindo coisa julgada, restando a impossibilidade de nova discussão do mérito da controvérsia. No entendimento de Wambier (2006, p. 628),

[...] os efeitos da sentença podem ser classificados em principais, anexos e secundários. Os efeitos principais estão previstos na própria sentença. São decorrência da sentença considerada como ato jurídico. Mais especificamente, os efeitos principais advêm diretamente do próprio conteúdo do comando (dispositivo) da sentença. Derivam da definição do destino do processo contido no dispositivo da sentença. Daí que, quando da procedência, os efeitos principais refletem o pedido imediato do autor. Se o autor pediu a condenação, o efeito principal da sentença de procedência é condenatório. Se pediu uma ordem, a sentença tem efeito principal mandamental - e assim por diante. 
Dessa forma, em relação aos efeitos principais, eles variam dependendo do tipo de sentença, ou seja, se for meramente declaratória, tais efeitos consistiriam no reconhecimento da existência de um direito à obtenção de uma modificação jurídica, se for constitutiva, constituiriam numa nova situação jurídica criada por ela e, por fim, se for condenatória, seus efeitos seriam o de permitir a instauração de uma execução forçada, ou seja, teriam o condão de impor ao devedor uma prestação. Contudo, há de se observar a ampliação do rol dos títulos judiciais executivos após a inclusão do art. 475, N no CPC, que possibilita a execução de sentença declaratória, desde que contenha todos os elementos da obrigação, conforme comentado anteriormente.

A eficácia da sentença arbitral decorre da lei e da vontade das partes, sendo que o limite de seus efeitos e da autoridade da coisa julgada é determinado pelo art 31 da Lei de Arbitragem. Assim sendo, este artigo estabelece igualdade de efeitos quanto à sentença proferida pelos órgãos do poder Judiciário e são produzidos entre as partes e seus sucessores ${ }^{7}$. Quanto ao limite da coisa julgada, comenta Furtado:

É correto afirmar que apenas as partes litigantes são alcançadas pela autoridade da coisa julgada, mas sua eficácia pode eventualmente alcançar terceiros, que não integram a relação processual. Pela teoria alemã dos efeitos reflexos da coisa julgada, são as partes atingidas 'diretamente' pela coisa julgada, mas terceiros podem sofrer 'indiretamente' tais efeitos. Os primeiros queridos e previstos pelos litigantes, os últimos, não queridos, nem previstos, mas inevitáveis (FURTADO, 1997, p. 112).

Ressalta Grinover (2007, p. 286) que, em razão da equiparação da sentença arbitral à sentença judicial, é necessário averiguar como opera em relação à decisão arbitral a "eficácia preclusiva relativamente às alegações deduzidas ou dedutíveis pelas partes no processo arbitral”.

Considerando as lições de Marques (1982, p. 238-9), tem-se que "a coisa julgada material tem como limites objetivos a lide e as questões pertinentes a esta, que foram decididas no processo". O doutrinador complementa o raciocínio especificando que "o que individualiza a lide, objetivamente, são o pedido e a causa petendi, isto é, o pedido e o fato constitutivo que fundamenta a pretensão". Nesse sentido, “a limitação objetiva da coisa julgada está subordinada aos princípios que regem a identificação dos elementos objetivos da lide", concluindo que "a coisa julgada alcança a parte dispositiva da sentença ou acórdão, e ainda o fato constitutivo do pedido (causa petendi)”.

\footnotetext{
${ }^{7}$ No direito comparado, diversas leis declaram expressamente que a decisão arbitral faz coisa julgada, entre elas o CPC francês e a Lei de Arbitragem portuguesa.
} 
Partindo dessas premissas Grinover (2007, p. 291) conclui que, por sua vez, a eficácia preclusiva da coisa julgada cobre não só o que foi discutido, mas também o que poderia ser discutido na fase cognitiva, de modo que o impedimento à rediscussão cobre o que foi ou o que poderia ter sido discutido.

As observações de Grinover (2007, p. 291) destinam-se justificar que em razão da equiparação da sentença arbitral à sentença judicial, também quanto à decisão arbitral é vedado "reabrir debate sobre questões de mérito que foram ou que poderiam ter sido suscitadas pelas partes”, evitando dar margem ao seu reexame.

Do ordenamento vigente extrai-se, pois, que a sentença arbitral é dotada de executividade e está elencada no rol de títulos executivos judiciais. Entretanto, em razão da carência de imperium nos poderes atribuídos ao árbitro, que impossibilita a realização de fato do comando contido em sua decisão, necessária a atuação da jurisdição estatal para a execução da sentença, considerada a disciplina contida no Código de Processo Civil.

A Lei 9.307/96 excluiu qualquer possibilidade de recurso da sentença arbitral pelo Poder Judiciário, sendo possível, no entanto, as partes pactuarem, dentro do procedimento arbitral, a revisão da decisão por outro órgão arbitral. Ocorrendo dúvida, contradição ou obscuridade, aplica-se a previsão do contido no art 30, I e II e parágrafo único do diploma legal específico, cujo equivalente corresponde aos embargos de declaração, delineados no Código de Processo Civil.

Cabe dizer, entretanto, que a decisão arbitral não está imune de controle estatal, subtraídas do âmbito desse controle questões relativas ao conhecimento do mérito e respectivas questões de fato e de direito pertinentes ao conflito decidido em sede arbitral. Tal controle consubstancia-se na "ação anulatória" prevista no art. 33 da Lei de arbitragem e nos "embargos do devedor", a serem opostos em caso de eventual execução de sentença arbitral mediante o não cumprimento espontâneo do decisum.

$\mathrm{Na}$ ação anulatória, segundo Figueira Junior (1999, p. 270):

O fundamento jurídico da demanda (causa de pedir próxima) repousará na demonstração de alguma das hipóteses elencadas no art 32 da Lei de Arbitragem e o objeto imediato (pedido) será a desconstituição da sentença arbitral através do comando declaratório a ser obtido da sentença judicial de procedência.

Em contrapartida, os embargos do devedor, enquanto via defensiva disponibilizada ao executado", "são estruturados como um 'processo incidente ao executivo”, segundo as lições de Dinamarco (2004, p. 637-9). Para Fux (2001, p. 1182) "objetivam os embargos desconstituir a causa hábil de execução, 
revelando índole preponderantemente constitutiva, posto apagar os atos executivos em geral".

Carmona (2006, p. 344) aventa que o legislador contempla "a possibilidade de cumulação de motivos de nulidade em sede de embargos, desde que o embargante oponha defesa dentro do prazo de 90 (noventa) dias a contar da notificação da sentença arbitral", bem como formula hipótese referente "ao manejo dos embargos após o prazo decadencial de 90 dias previsto na Lei de Arbitragem".

$\mathrm{Na}$ primeira hipótese, trata-se de cumulação de demandas - demanda anulatória da Lei de Arbitragem e embargos à execução nos termos do CPC - ao que Carmona (2006, p. 344-5) explica:

Permitiu-se expressamente - ainda que de forma elíptica- que o embargante utilizasse uma mesma via processual para alegar tantos motivos de impugnação do laudo previstos no art. 32 da Lei como os motivos de impugnação previstos no art. 741 do Código de Processo Civil, ainda que o acolhimento de um ou outro motivo de impugnação não tenha o mesmo efeito.

Mencione-se que ultrapassado o prazo decadencial para a propositura da ação anulatória, será possível ao embargante argüir apenas as matérias contidas no art. 475-L do CPC. Nesse contexto, há de ser ressaltado que após as alterações promovidas pela Lei 11.232/05 no CPC, a matéria passível de ser argüida, em sede de embargos de execução de sentença arbitral corresponde à matéria pertinente à impugnação ao cumprimento de sentença - art. 475 - L.

Anote-se que o disposto no art. 33, $\S 3^{\circ}$, da Lei de Arbitragem apresenta nomenclatura desatualizada, posto não mais haver previsão no CPC de execução de título judicial nem seus embargos e sim a fase de cumprimento de sentença e sua impugnação.

\section{DA AÇÃO DECLARATÓRIA DE NULIDADE}

As hipóteses de nulidade de sentença são contempladas no artigo 32 da Lei de Arbitragem ${ }^{9}$. Ao considerar que a sentença arbitral produz efeitos análogos

${ }^{8}$ Para Lucon (1996, p. 80-4) "embora exista uma limitação da cognição no que se refere à amplitude das matérias a serem conhecidas pelo juiz e debatidas pelas partes (cognição parcial no plano horizontal) a cognição será exauriente, isto é ela será completa relativamente à profundidade das matérias passíveis de serem conhecidas e debatidas".

${ }^{9}$ Art. 32. É nula a sentença arbitral se: I - for nulo o compromisso; II - emanou de quem não podia ser árbitro; III - não contiver os requisitos do art. 26 desta Lei; IV - for proferida fora dos limites da convenção de arbitragem; V - não decidir todo o litígio submetido à arbitragem; VI - comprovado que foi proferida por prevaricação, 
àqueles próprios da sentença judicial, Ricci (1999, p. 49) pondera 'necessária a aplicação dos princípios e dos conceitos que dominam a disciplina da nulidade da sentença pronunciada pelo Poder Judiciário'.

Como se pode depreender, a disciplina da nulidade dos atos processuais é complexa, existindo vários tipos de nulidade: relativa, absoluta, sanável e insanável, sendo princípio do direito positivo de que os atos nulos produzem efeitos até que seja decretada a nulidade (art 288 do CPC). Obtempera Ricci (1999, p. 50):

Por esta razão, afirma-se que a nulidade dos atos processuais não tem relação com a nulidade dos atos de direito material (dominada pela regra da ineficácia do ato nulo), entendendo-se que se assemelha à anulabilidade de direito material, segundo a qual são produzidos os efeitos anuláveis, que podem, entretanto, ser eliminados.

Ao tratar da questão dos vícios do ato processual, Cintra, Grinover e Dinamarco (2008, p. 366) asseveram que:

Mesmo quando eivado de vício que determina a sua nulidade, porém, o ato processual considera-se válido e eficaz, deixando de sê-lo apenas quando um pronunciamento judicial decrete a nulidade: a ineficácia do ato decorre sempre do pronunciamento judicial que lhe reconhece a irregularidade. Assim sendo, o estado de ineficaz é subseqüente ao pronunciamento judicial (após a aplicação da sanção de ineficácia - diz-se, portanto, não sem alguma impropriedade verbal, que o ato nulo é anulado pelo juiz). Não se compadeceria com a natureza e fins públicos do processo a precariedade de um sistema que permitisse a cada qual das partes a apreciação da validade dos atos, podendo cada uma delas negar-se a reconhecê-los, mediante a simples alegação de nulidade, diluindo-se sua sujeição à autoridade do juiz e pulverizando-se as garantias de todo o processo.

Nessa vertente, tem-se que a sentença possui aptidão para produzir efeitos ainda que com eventual presença de nulidade, podendo ser considerado que, mesmo a sentença qualificada como nula sob a égide das normas processuais, é na verdade anulável se impugnada. Dessa forma, a coisa julgada material ${ }^{10}$

concussão ou corrupção passiva; VII - proferida fora do prazo, respeitado o disposto no art. 12, inciso III, desta Lei; e VIII - forem desrespeitados os princípios de que trata $\mathrm{o}$ art. $21, \S 2^{\circ}$, desta Lei.

${ }^{10}$ Para Luiz Guilherme Marinoni (2008, p. 56), "a coisa julgada, portanto, não é uma regra preocupada com o conteúdo do discurso, mas sim uma condição para que o discurso seja um discurso institucional limitado no tempo e, destarte, um discurso jurídico propriamente dito. $\mathrm{Na}$ verdade, se a discussão jurídica não tiver um termo a partir do qual a decisão não possa ser questionada, não haverá sentido em falar em discurso jurídico nem muito menos em realizá-lo. Ora, um discurso jurídico incapaz de se estabilizar é uma contradição em termos, já que o poder, fundamento do discurso jurídico, imprescinde do recrudescimento. É por isto que um discurso aberto à eterna discussão jamais será um discurso jurídico ou um discurso do poder estatal, mas tãosomente um discurso prático-geral". 
possui eficácia sanatória com relação às nulidades do processo e da sentença. Preleciona Wambier (2003, p. 21-2), nesse sentido:

A coisa julgada é instituto cuja função é a de estender ou projetar os efeitos da sentença indefinidamente para o futuro. Com isso, pretende-se zelar pela segurança extrínseca das relações jurídicas, de certo modo em complementação ao instituto do processo, pois que assegura a irreversibilidade das situações jurídicas cristalizadas endoprocessualmente. Esta segurança extrínseca das relações jurídicas gerada pela coisa materialmente traduz-se na impossibilidade de que haja outra decisão sobre a mesma pretensão.

Nas sentenças judiciais, após o trânsito em julgado, as nulidades se transformam em rescindibilidades que, com o decurso do prazo decadencial para a ação rescisória, embora subsistam eventuais vícios, não estarão mais sujeitos a qualquer espécie de impugnação.

Entretanto, isso não ocorre nas sentenças arbitrais, posto que não há previsão, no diploma legal, de ação rescisória das decisões arbitrais. Uma vez escoado o prazo decadencial de propositura de ação para desconstituição da sentença proferida em sede de arbitragem, outro remédio não há para sanar a nulidade processual. Tal distinção é justificada, em parte, pela exigência de celeridade, típica da arbitragem.

$\mathrm{Na}$ doutrina, há crítica acentuada no sentido de que parte das hipóteses apontadas no dispositivo legal trata de anulabilidades e não de nulidades, sendo considerados, portanto, revestidos de nulidade absoluta apenas as hipóteses apontadas nos incisos I, II, VI, VII e VII, do art. 32, enquanto os demais incisos apresentam hipóteses de nulidade relativa. Nesse sentido, Figueira Junior (1999, p. 270) preleciona:

Dependendo da hipótese de violação ocorrida, decretará o juiz a nulidade da decisão (nulidade do compromisso arbitral, emanada de quem não poderia ser nomeado árbitro, proferida por prevaricação, concussão ou corrupção passiva, se fora do prazo estabelecido no compromisso arbitral, for desrespeitado o princípio do devido processo legal) (incs. I, II, VI, VII e VIII do art. 32) ou declarará a nulidade da sentença arbitral e determinará que o árbitro ou tribunal profira nova decisão (se não contiver os requisitos do art. 26, se for proferida citra, ultra ou extra petita) (incs. III, IV, V do art. 32 e art. $33, \S 2^{\underline{o}}$ ).

O método adotado pelo legislador pátrio para a solução das nulidades apontadas no art. 32, sob o comentário de Carmona (2006, p. 339), é de que:

anulado o laudo, não pode o juiz togado passar ao exame da causa. Se a nulidade afeta apenas o laudo, e não a convenção arbitral, devolve-se ao árbitro (ou aos árbitros) a causa para a nova decisão; se a nulidade afeta a convenção de arbitragem ou a estrutura do juízo arbitral (substancialmente, a confiabilidade dos árbitros, que se mostraram parciais ou negligentes), destrói-se a própria arbitragem, cabendo ao interessado, livremente, procurar a tutela judicial de seus direitos. 
Por fim, a todas as hipóteses elencadas no artigo 32 a lei revestiu da qualidade de fundamento para propositura de ação anulatória de sentença com a finalidade de desconstituição dos efeitos da decisão arbitral.

Não obstante, cumpre comentar que embora parte da doutrina considere que as hipóteses apontadas no artigo em comento sejam numerus clausus, notase, através de uma análise mais apurada, que se trata de rol exemplificativo, posto que eventual ação de nulidade poderá ser proposta perante o poder judiciário competente, com base em outros fundamentos que não os apontados no referido artigo, mas fundamentada no direito positivo, aqui considerado todo o sistema de ordenamento jurídico vigente.

À decisão arbitral a lei outorga eficácia e autoridade, sendo necessário, conforme ensinamentos de Cachapuz (2000, p. 211), que "para oferecer equivalência à sentença judiciária, com seus sectários (tanto exequatur quanto as características da imutabilidade da coisa julgada), deve estar imune de nulidade”. É necessário, portanto, para a desconstituição da decisão, a propositura de ação declaratória de nulidade da sentença arbitral.

Para Wambier (2007, p. 140) “a nulidade é um estado de irregularidade que leva (ou tende a levar) à ineficácia. A ineficácia é, pois, neste sentido, uma conseqüência da decretação de nulidade, que é, direta ou indiretamente, uma infração à lei”. A doutrina ao relacionar a nulidade com a validade da sentença distinguindo-a da eficácia, que se refere à produção de efeitos da sentença, aponta situação em que mesmo nula, a sentença pode alcançar eficácia se não houver declaração judicial da nulidade.

A distinção, segundo Wambier (2007, p. 286), entre nulidades e anulabilidades processuais reside no fato de que "só aquelas sobrevivem à formação da coisa julgada, e, em relação a elas, no processo, não há preclusão”.

Partindo desse raciocínio, é possível a argüição de nulidades processuais após a formação da coisa julgada, no âmbito da arbitragem, quer seja em sede de ação autônoma de nulidade de sentença, de natureza desconstitutiva, ou de embargos do devedor, na hipótese de sentença arbitral de natureza condenatória mediante a não satisfação espontânea do julgado pela parte sucumbente. De conformidade com Muniz (2006, p. 144):

Porém é bom salientar que, se a sentença arbitral for meramente declaratória ou constitutiva, o interessado deverá, obrigatoriamente, intentar ação de nulidade, sob pena de, em não o fazendo, não mais poder discutir os vícios apresentados, posto que, não cabe ação rescisória de sentença arbitral. Se a decisão for condenatória, poderá o devedor optar por argüir a nulidade em embargos do devedor, conforme o art. 741 do Código de Processo Civil que trata da execução de título judicial. 
A ação prevista pelo art. 33 da Lei 9.307/96 tem natureza constitutiva cujo escopo não é de declarar a ineficácia da sentença, mas fulminar os efeitos que ela tenha produzido. Sua pretensão é de eliminar a capacidade da sentença de produzir efeitos. Entretanto, Amorim Filho (1997, p. 726) preleciona de forma sintética:

[...] tem-se um critério dotado de bases científicas, extremamente simples e de fácil aplicação, que permite, com absoluta segurança, identificar, a priori, as ações sujeitas à prescrição ou a decadência, e as ações perpétuas (imprescritíveis)'. Deste modo: '10. Estão sujeitas a prescrição: todas as ações condenatórias e somente elas (arts 177 e 178 do CC); 2o: Estão sujeitas a decadência (indiretamente), isto é, em virtude da decadência do direito a que correspondem: as ações constitutivas que têm prazo especial de exercício fixado em lei; $3^{\circ}$ : São perpétuas (imprescritíveis): a) as ações constitutivas que não tem prazo especial de exercício fixado em lei; e b) todas as ações declaratórias’. Várias inferências imediatas podem ser extraídas daquelas três proposições. Assim: a) não há ações condenatórias perpétuas (imprescritíveis), nem sujeitas a decadência; b) não há ações constitutivas sujeitas à prescrição, e o c) não há ações declaratórias sujeitas à prescrição ou a decadência.

Em essência, as ações declaratórias, segundo Chiovenda (1942, p. 62), "não se destinam a fazer cessar um estado de fato contrário, em sentido próprio, mas a declarar qual é o estado de fato conforme ao direito, fazendo cessar a propósito o estado de incerteza”, e, ao buscar fundamentação nas lições de Liebman, citado em nota de sua obra, às folhas 293: "A ação não está sujeita à prescrição, como em geral todas as ações declaratórias, porque tende simplesmente a fazer resultar de modo certo um estado de coisas já existente e perfeitamente legítimo, que o decurso do tempo, só, não pode modificar”. Nessa linha, sustentou Pontes de Miranda (1955, p. 100):

Não há prescrição da ação declaratória negativa ou positiva. O titular da ação de nulidade não precisa propô-la, basta que alegue a nulidade ao ter-se querido emprestar ao ato jurídico algum efeito. Para evitar que se lhe atribua tal efeito, que o ato não tem, alega a nulidade, dando ensejo a que o juiz desconstitua $\mathrm{o}$ ato jurídico incidentemente, como poderia desconstituir de ofício. Não se compreenderia que o tempo apagasse o que o juiz não pode suprir, nem os próprios interessados ratificar.

Daí dizer que a ação declaratória objetiva a eliminação da incerteza quanto à existência ou não de uma relação jurídica, ou da falsidade, ou autenticidade de um documento. Nas lições de Dinamarco (2004, p. 219) resta claro seu objetivo:

É de sua essência e natureza a afirmação ou negação da existência de uma relação jurídica, direito ou obrigação, ou a de seus elementos e quantificação do objeto. O resultado da sentença declaratória, seja positiva ou negativa, é invariavelmente a certeza - quanto à existência, inexistência ou valor de relações jurídicas, direitos e obrigações. Essa é sua utilidade social institucionalizada, sabido que a 
incerteza é fonte de insegurança e desacertos no giro dos negócios e em todos os aspectos da vida em sociedade.

No entanto, em sede de doutrina, algumas situações são consideradas de vício tão grave ${ }^{12}$ que impedem a produção dos efeitos da sentença arbitral, entre eles a falta de dispositivo da sentença, a sentença proferida sem citação da parte adversa considerada revel no processo e a falta de pressupostos processuais ${ }^{13}$, ensejando a inexistência jurídica da sentença ${ }^{14}$.

Para Wambier (2007, p. 293) "sobre sentenças inexistentes não pesa autoridade de coisa julgada”. Em tais circunstâncias, a impugnação tem natureza declarativa, e o escopo de tal ação é de constatar que a sentença não produziu efeitos, nem coisa julgada material. Assim declara:

Acertada é a opinião segundo a qual o meio adequado para retirar definitivamente do mundo jurídico as sentenças inexistentes é o da ação declaratória, que, no caso, é imprescritível. Diz-se, quase unanimemente na doutrina, que as ações declaratórias são imprescritíveis (WAMBIER, 2007, p. 475).

A questão que ora se apresenta é: No caso de ocorrência de inexistência de sentença arbitral, mediante os fundamentos acima demonstrados, como se resolveria a situação fática surgida?

A utilização de ação de natureza declaratória, a qualquer tempo, com fins de vulnerar a sentença arbitral inexistente, deve ser amplamente considerada, posto que, enquanto tutela jurídica cuja disponibilidade está inserida na ordem processual brasileira vigente, a exclusão de sua aplicabilidade às hipóteses, acima apontadas, representará ofensa à garantia constitucional da ação e do acesso à justiça.

\section{CONCLUSÃO}

Estas considerações parecem oportunas e necessárias. Pode-se afirmar em sede de conclusão que: a) a alteração legislativa ocorrida com o advento da Lei

${ }^{12}$ Cite-se Arruda Alvim, Egas D Moniz de Aragão, Tereza Arruda Alvim Wambier, Enrico Tullio Liebman, Humberto Theodoro, Ovídio A. Baptista da Silva e Cândido Rangel Dinamarco.

${ }^{13}$ No âmbito da arbitragem, a estipulação de compromisso válido, que estabeleça a controvérsia a ser decidida pelos árbitros, pode ser qualificada como pressuposto processual.

${ }^{14}$ Cintra et al observa que "parte da doutrina nega que haja essa categoria de atos inexistentes, falando, antes, em nulidade absoluta. [...] A divergência como se vê, é porém mais terminológica que real. Mas como poderia chamar de nulidade relativa aquela que o juiz decreta de ofício e que muitas vezes sobrevive à própria coisa julgada?" (2008, p. 370-1). 
11.232/2005 modificou o conceito de sentença e conseqüentemente a estrutura da sistemática processual em que se espelhou a Lei 9.307/96; b) tal alteração propicia a utilização de sentença arbitral parcial, posto não haver dispositivo que vede expressamente tal modalidade de sentença em sede arbitral; c) Em razão da atual sistemática adotada pelo CPC para o cumprimento de sentença, incidirá a hipótese do art 476-J, possibilitando a aplicação de multa ao devedor condenado e inadimplente; Tratando-se de sentença arbitral mandamental ou executiva lato sensu o procedimento a ser adotado para seu cumprimento é o determinado pelos artigos 461 e 461-A do CPC, nos termos do arts 475-I e 644 do mesmo diploma legal; d) da redação dada ao art 475-N do CPC extrai-se que as sentenças declaratórias podem constituir títulos executivos desde que tenha todos os elementos de norma jurídica concreta relativa à obrigação, incluindo essa modalidade no âmbito da execução de sentença arbitral; e) a matéria passível de ser argüida em sede de embargos de execução de sentença arbitral resta hoje disposta no artigo 475-L do CPC, que não prevê mais a execução de título judicial nem seus embargos, sendo adotado sistema de cumprimento de sentença em razão da modificação propiciada pela Lei 11.232/05; f) nos casos em que a sentença arbitral apresente vício grave que impeça a produção de seus efeitos, ensejando sua inexistência jurídica é admissível sua impugnação, através de ação de natureza declarativa, mesmo escoado o prazo de 90 dias determinado pelo $§ 1^{\circ}$ do art 33 da Lei 9.307/96.

\section{REFERÊNCIAS}

AMORIM FILHO, Agnelo. Critério científico para distinguir a prescrição da decadência e para identificar as ações imprescritíveis. Revista dos Tribunais, São Paulo, ano 86, v. 744, p. 725-50, out. 1997.

BELLINETTI, Luiz Fernando. Sentença civil: perspectivas conceituais no ordenamento jurídico brasileiro. São Paulo: RT, 1994.

CACHAPUZ, Rozane da Rosa. Arbitragem: alguns aspectos do processo e do procedimento na Lei no 9.307/96. Leme: LED - Editora de Direito, 2000.

CARMONA, Carlos Alberto. Arbitragem e processo: um comentário à Lei 9307/96. São Paulo: Malheiros, 2004.

Arbitragem e processo: um comentário à Lei nº 9.307/96. 2 ed. rev, atual e ampl. São Paulo: Atlas, 2006.

. Ensaio sobre a sentença arbitral parcial. Revista de Processo, São Paulo, v. 33 , n. 165 , p. $9-28$, nov. 2008. 
CINTRA, Antonio Carlos de Araújo; GRINOVER, Ada Pelegrini; DINAMARCO, Cândido Rangel. Teoria geral do processo. 24. ed. rev. e atual. São Paulo. Malheiros Editores, 2008.

CHIOVENDA, Giuseppe. Instituições de Direito Processual Civil. São Paulo: Saraiva, 1942. v. 1.

DINAMARCO, Cândido Rangel. Instituições de Direito processual Civil. 4. ed. rev. e atual. São Paulo: Malheiros Editores, 2004. v. 1, 3, 4.

FIGUEIRA JUNIOR, Joel Dias. Arbitragem: jurisdição e execução: análise crítica da Lei 9.307, de 23.09.1996. São Paulo: Editora Revista dos Tribunais, 1999.

FURTADO, Paulo; BULOS, Uadi Lammêgo. Lei da arbitragem comentada. São Paulo: Saraiva, 1997.

FUX, Luiz. Curso de direito processual civil. Rio de Janeiro: Forense, 2001.

GRINOVER, Ada Pelegrine. Arbitragem. Execução. Ação para reconhecer a invalidade da arbitragem. Embargos à execução. Identidade. Revista de Processo, São Paulo, ano 32, n. 146, p. 271-95, abr. 2007.

LUCON, Paulo Henrique dos Santos. Embargos à execução. São Paulo: Saraiva, 1996.

MARINONI, Luiz Guilherme. Curso de processo civil: teoria geral do processo. São Paulo: Editora Revista dos Tribunais, 2006. v. 1.

. Coisa Julgada Inconstitucional: a retroatividade da decisão de (in) constitucionalidade do STF sobre a coisa julgada: a questão da relativização da coisa julgada. São Paulo: Editora Revista dos Tribunais, 2008.

MARQUES, José Frederico. Manual de direito processual civil. São Paulo, Saraiva, 1982. v. 3.

MEDINA, José Miguel Garcia. Execução. São Paulo: Editora Revista dos Tribunais, 2008.

. A sentença declaratória como título executivo-considerações sobre o art 475-N,I, do CPC. Revista de Processo, São Paulo, ano 31, n. 136, p. 58-80, jun. 2006.

MIRANDA, Pontes de. Tratado de direito privado. Rio de Janeiro: Borsoi, 1955. t. 6 . 
MUNIZ, Tânia Lobo. Arbitragem no Brasil e a Lei 9.307/96. Curitiba: Juruá Editora, 2006.

NERY JUNIOR, Nelson. Princípios de processo civil na Constituição Federal. 7. ed. rev. e atual. São Paulo: Editora Revista dos Tribunais, 2002.

PARIZZATO, João Roberto. Arbitragem, comentários à Lei 9.307, de 23.09.96. São Paulo: Editora de Direito, 1997.

RICCI, Edoardo F. Reflexões sobre o art 33 da Lei de Arbitragem. Revista de Processo, São Paulo, ano 24, n. 93, p. 45-59, jan./mar. 1999.

SANTOS, Juliana Cavalcante dos Santos. O efeito executivo das sentenças declaratórias: uma visão atual das recentes alterações dos efeitos das sentenças declaratórias e seu caráter executivo numa preocupação clara do processo civil em dar-lhe efetividade e melhor oferecer a prestação jurisdicional. Revista de Processo, São Paulo, ano 33, n. 157, p. 182-97, mar. 2008.

SCAVONE JUNIOR, Luiz Antônio. Manual de arbitragem. 2. ed. rev., atual. e ampl. São Paulo: Editora Revista dos tribunais, 2008.

VARGAS, Jorge de Oliveira. Conceito de sentença e o recurso daquela que não extingue o processo: apelação ou agravo de instrumento? Revista de Processo, São Paulo, ano 32, n. 148, p. 111-8, jun. 2007.

ZANZUCCHI, Marco Tullio. Diritto processuale civile. Milano: Giuffrè, 1964. v. 1 .

ZAVASCKI, Teori Albino. Sentenças declaratórias, sentenças condenatórias e eficácia executiva dos julgados. Revista de Processo, São Paulo, ano 28, n. 109, p. 45-56, jan./mar. 2003.

WAMBIER, Luiz Rodrigues. Sentença civil: liquidação e cumprimento. São Paulo: Editora Revista dos Tribunais, 2006.

WAMBIER, Tereza Arruda Alvim. Nulidades do processo e da Sentença. 6. ed. São Paulo: Editora Revista dos Tribunais, 2007.

WAMBIER, Tereza Arruda Alvim; MEDINA, José Miguel Garcia. O dogma da coisa julgada: hipóteses de relativização. São Paulo: Editora Revista dos Tribunais, 2003. 